\title{
New Blacks: Language, DNA, and the Construction of the African American/Dominican Boundary of Difference
}

\author{
Aris Moreno Clemons
}

Citation: Clemons, Aris Moreno. 2021. New Blacks: Language, DNA, and the Construction of the African American/Dominican Boundary of Difference. Genealogy

5: 1. https://dx.doi.org/10.3390/ genealogy5010001

Received: 10 October 2020

Accepted: 17 December 2020

Published: 24 December 2020

Publisher's Note: MDPI stays neutral with regard to jurisdictional claims in published maps and institutional affiliations.

Copyright: (c) 2020 by the author. Licensee MDPI, Basel, Switzerland. This article is an open access article distributed under the terms and conditions of the Creative Commons Attribution (CC BY) license (https: / / creativecommons.org/ licenses/by/4.0/).
Department of Spanish and Portuguese, The University of Texas at Austin, Austin, TX 78712, USA; amc6957@utexas.edu

\begin{abstract}
Given the current political climate in the U.S.- the civil unrest regarding the recognition of the Black Lives Matter movement, the calls to abolish prisons and U.S. Immigration and Customs Enforcement (ICE) detention, and the workers' rights movements-projects investigating moments of inter-ethnic solidarity and conflict remain essential. Because inter-ethnic conflict and solidarity in communities of color have become more visible as waves of migration over the past 50 years have complicated and enriched the sociocultural landscape of the U.S., I examine the ways that raciolinguistic ideologies are reflected in assertions of ethno-racial belonging for Afro-Dominicans and their descendants. Framing my analysis at the language, race, and identity interface, I ask what mechanisms are used to perform Blackness and/or anti-Blackness for Dominican(-American)s and in what ways does this behavior contribute to our understanding of Blackness in the U.S.? I undertake a critical discourse analysis on 10 YouTube videos that discuss what I call the African American/Dominican boundary of difference. The results show that the primary inter-ethnic conflict between Dominican(-Americans) and African Americans was posited through a categorization fallacy, in which the racial term "Black" was conceived as an ethnic term for use only with African Americans.
\end{abstract}

Keywords: race; Blackness; Latinidad; raciolinguistics; language and identity

\section{Introduction}

On Tuesday 25 June 2019, Belcalis Almenzár, better known as Cardi B, took to Instagram live in order to defend her Blackness. Her aim was to clarify confusion about her ethno-racial identity following a wave of criticism resulting from her Black Entertainment Television (BET) Album of the Year and Best Female Hip-Hop Artist awards. People argued that she should not be eligible for the awards because she is not Black, maintaining that her use of the Spanish language and her previous claims of Latinidad precluded her from Blackness. This policing of Blackness is not new (Fanon 1967; Davis 2010; Shange 2019); however, increased migration from Latin America and the Caribbean over the last fifty years has complicated and enriched the sociocultural landscapes of the U.S. In her response, Cardi B attempts to dispel the myth of the mutual exclusivity between Blackness and Latinidad (Flores and Román 2009; Cahuas 2019). "People don't be understanding shit. It's like, 'Cardi's Latin, she's not Black'. And it's like, 'Bro, my features don't come from ... white people f-ing, Ok'? ... But because Cardi speaks Spanish to people, she's not Black even though we have similar features, same skin complexion. But no, they want to not put Cardi in it because I speak Spanish". She then goes on to explain that the problem is a fundamental misunderstanding of the differences between race, ethnicity, and nationality. Attributing this ignorance to a lack of proper education in the U.S. school systems, Cardi B arrives at the core of the matter regarding public discussions of race in the United States: first, that as a society we have not yet agreed upon set definitions for terms of identity that are used in everyday language; and second, that part of the reason that we have not agreed is because there are societal institutions that either willfully obscure our understandings or 
that at the very least have done very little to historicize the rise of these notions (Nagel 1994, 2003; Telles 2014).

I recognize these moments of identity negotiations as both personal and political. In my own life, being the child of an African American father and an Afro-Caribbean mother, I have lived on the margins of identification. Often, these choices were made for me, given my dark complexion and racialized features. Nonetheless, significant travels outside the United States has shown me that my features can be (and are often) read differently in different locations. Moreover, I have learned that the political projects of race and racialization in different sociopolitical contexts often bear heavily on my own construction of self. The complexity of racial constructions becomes acute when considering the political implications of who gets to authentically claim identification within a particular group. Think for example of the ways that Barack Obama has been positioned as the first Black president and Kamala Harris as the first Black vice president elect. These politicians and the political organizations on which they have situated their careers have relied on the maintenance of racial formations developed during U.S. colonial formations.

The mutability of racial categories has led the majority of social and natural scientists to an agreement that race is constructed socially (Boas 1982; Montagu 1997; Omi and Winant 2014). Literature across the social sciences investigates the use of race as a tool to construct and maintain power within a society (Fanon 1967; Lopez 1994; Hall [1980] 1996; Crenshaw 1991; Delgado and Stefancic 2017). It is this organization of power that leads sociologists Omi and Winant (2014) to posit race as a "master category", noting that "race is a fundamental organizing principle of social stratification. It has influenced the definition of rights and privileges, the distribution of resources and the ideologies and practices of subordination and oppression" (p. 107). Moreover, the authors assert that the corporeal aspects of race, i.e., the distinction created between "white men and the others whom they ruled as patriarchal masters" (p. 108), gives "race" its ability to dominate all other social categories including gender, social class, and sexuality. Nonetheless, Omi and Winant note a key conundrum for those who theorize race, in that "race and racial meanings are neither stable nor consistent" (p. 2). The mutability of racial meaning suggests that categories that are used to define racial identity are in constant flux, with emerging categories alongside the reconstitution of existing categories in the struggle for sociopolitical, economic, and cultural power. Nonetheless, boundaries exist and individuals are ultimately unable to escape some form of category ratification - an inevitable click on a U.S. census classification for race and ethnicity, a school or grant application, a health care form. In making these selections, individuals are collectively defining the bounds of these categories, pushing up against the walls of what has been dictated to them. The question remains, how exactly are these boundaries created and what are the effects of the boundaries? Given the differential social constructions of race and ethnicity in contexts of origin and migration, the competition for scarce resources among marginalized groups, and the complex relationships with differing colonial histories, it is nearly impossible to have a comprehensive understanding of Blackness in the United States from a singular disciplinary lens. This study thus takes up concepts developed in linguistics, sociology, anthropology as well as critical race theories from both Black and Latinx studies. In doing so, I attempt the development of an initial framework for an understanding of Blackness as it currently exists for differing ethnic groups that represent Black subjectivities in the U.S.

I situate Blackness as an organizing concept of American life (Hartman 1997; Wilderson 2010; Kendi 2019). That is, much like Hartman's construction of the subjugated liberal individual that is at once equal yet forever inferior, American society exists within a hierarchy-one that necessitates the continual reconstitution of white supremacy for a reproduction of all that has been defined as "American life". Blackness, as a concept, therefore becomes the tool by which white supremacy can claim social capital. This capital, which can be traced back to the rules and regulations that structured the U.S. as a slaveholding society, manifests in the ability to enact policies, both legal and social, over its public. "Here I want to focus on a singular aspect of the slave's existence in civil society- 
the submission of the slave to all whites ... to be sure, the laws of slavery subjected the enslaved to the absolute control and authority of any and every member of the dominant race. At the very least the relations of chattel slavery served to enhance whiteness by racializing rights and entitlements, designating inferior and superior races, and granting whites' dominion over blacks" (Hartman 1997, p. 24). Hartman describes the condition of Blackness in the United States as always posited in relation to the dominant, such that allowing Black self-determination becomes a threat to the very existence of whiteness. Moreover, whiteness is forever reliant on Blackness as a way to re-imagine, re-construct, and re-insert itself as the dominant race (Bloom Forthcoming).

Nevertheless, this refashioning of whiteness has never been able to successfully stifle the move toward Black self-determination, evidenced by ever-growing movements such as the Black Power movement of the 70s and more recently the Black Lives Matter movement (Hooker 2016). I argue that to understand Black self-determination, we must look beyond the Black/white binary in negotiations of race and identity in the Americas. The current project therefore explores several moments of cross-ethnic conflicts and solidarities and the role that language plays in mapping the margins of identity and ethno-racial categorizations for Dominican(-American)s in the United States. I use the term ethno-racial throughout this article to note the inextricable link between ethnicity, as heritage linked to a particular nation state, and race, as the corporeal manifestation of colonial categorization projects. In certain cases, I will refer to the use of nationality as a distinguishing characteristic that was taken up in my data. In these cases, nationality refers to the political belonging or citizenship in a particular nation state as it is currently defined. Lastly, I use the terms pan-racial to refer to racial categories that cannot be linked to one particular ethnicity or nationality. What should be noted is that all of these categories are constructed in contextualized and flexible ways. As such, the marking of boundaries of belonging is complex and should be considered in relation to sociohistoric moments, narratives of identity, and political commitments (Yuval-Davis 2011). Through investigations of interactions between members of the pan-racial group-Black-we are able to theorize about the ways that we define boundaries of belonging [at a particular time in a particular place and context]. In other words, we are able to negotiate where Afro-Latinxs, Afro-Caribbeans, and Africans and their U.S.-born children fit into the schema of Blackness in this country. More importantly, and for our purposes here, we can begin to empirically theorize race through analyses of language and language ideologies. In this study, I examine how four raciolinguistic ideologies are reflected in assertions of ethno-racial belonging for Afro-Dominicans and their descendants in the United States. I formulate my investigation with two guiding questions. What linguistic ideologies are implicated in the construction of Blackness for Dominicans and Dominican-Americans in the United States? And, what mechanisms are used to create what I call the African American/Dominican boundary of difference?

In centering Blackness in the United States, I focus on Dominican(-American)s for a variety of reasons, including the numerous linguistic repertoires to which Dominicans have access and employ in their daily lives (Bailey 2000, 2007; Nilep 2006; Rubinstein-Ávila 2007); research has shown that Dominicans contest socially constructed race in the United States (Bailey 2000, 2002; Duany 1998, 2008); and the unique historical situation of the enslaved and freed African populations in the Spanish-controlled region of Quisqueya (the indigenous name of the island which now hosts the Dominican Republic and Haiti) (Torres-Saillant 1999; Candelario 2007). Further, Dominicans have been racialized both in the Dominican Republic - as a result of the tumultuous history of colonialism and subsequent imperialism-and in the United States, as transnational beings. Thus, in the move toward Dominican self-determination, there is often an abrupt and contradictory negotiation of the ideological rupture between Blackness and Latinidad. In this case, a focus on Dominican subjectivities allows us to understand how the project of Latinidad is implicated in the refashioning of Blackness as it has historically existed in the United States.

Examining people's choices in regards to identity (terms) can be taken up through the lens of linguistics. It has long been understood that language performances shift 
in relation to interaction (Ochs et al. 1992; Fairclough 2001; Alim et al. 2016; Rosa and Flores 2017), and that these interactions are integral in the understanding of self and others (Bucholtz and Hall 2005; Coupland 2007). In other words, processes of dialectical language production are closely aligned with the processes of dialectical ethno-racial construction (Ochs et al. 1992; Nagel 1994). Further, as Ochs (1993) argues, "speakers attempt to establish the social identities of themselves and others through verbally performing certain social acts and verbally displaying certain stances" (p. 288). In order to explore the combined process of ethno-racial identification and shifting linguistic practices, I call on the concept of raciolinguistic enregisterment. Rosa and Flores (2017) submit raciolinguistic enregisterment as "an overarching framework with which to investigate relations among prevailing sociolinguistic concepts that are often approached as distinct phenomena, such as code-switching, style-shifting, footing" (p. 11). So, where the concept of linguistic enregisterment was previously defined as the process "whereby distinct forms of speech come to be socially recognized (or enregistered) as indexical of speaker attributes by a population of language users" (Agha 2005, p. 38), Rosa and Flores incorporate the "racial emblematization" inherent in many of these processes. Thus, raciolinguistic enregisterment refers to processes whereby distinct forms of linguistic practices become racialized. In this study, I expand the concept of raciolinguistic enregisterment to theorize about how certain ideologies that link language, race, and identity are central to our understanding of category binding. The framework of raciolinguistic enregisterment not only allows for an analysis of identity performances of individuals, but also for an analysis of the discourses complicit in the construction of ethno-racial boundaries, therefore allowing for a more nuanced understanding of Blackness as it currently exists in the United States.

In addition to the linguistic expressions of identities taken up through raciolinguistic enregisterment, the "external validation of individual or group ethnic boundaries" is an important aspect in the discursive processes of ethnic categorizations. According to Bonnie Urciuoli (1995), linguistic forms (i.e., language practices), are "the shape in which border making elements come [to be]" (p. 538). Urciuoli describes "borders" as the place where commonalities end and notes the symbolic possibilities for language to do that work. A border can therefore be a place where mutual intelligibility is no longer possible. While this was originally applied to the actual ability to understand linguistic forms, I contend that mutual intelligibility also occurs at the ideological level, whereby a disagreement on ideological premises is more difficult to overcome than a linguistic misunderstanding. Thus, my analysis of linguistic ideologies becomes an analysis of the construction of bounded ethno-racial categories and their connected bounded linguistic categories. I, therefore, take up the concept of stance in the interactional ideological construction of self and others. Stance is defined, in this case, as the way that individuals signal relationships to particular concepts through linguistic choices (Johnstone 2007, 2009). In the current paper, the multilectal nature of ethno-racial performance and negotiation are enregistered through explicit pronouncements of raciolinguistic ideologies examined through a critical stance-taking analysis, adapted from Kiesling et al. (2018).

\section{Materials and Methods}

\subsection{Procedures}

In order to explore the construction of Afro-Latinidades through the ethno-racial pronouncements of Dominican Americans and other Black diasporic beings, I begin with a critical discourse analysis (Fairclough 2001) of ten YouTube videos and selected comments posted between 2018 and 2020. I follow with a critical conversation analysis of stance taking in the comment section of the original posts. I adapt an approach developed by Kiesling et al. (2018) in their analysis of Reddit online forums. The concept of stance is defined by Kiesling et al. as "the discursive creation of a relationship between a language user and some discursive figure, and to other language users in relation to that figure" (p. 687). While the authors use a grounded theory approach to investigate the emergence of discursive figures - called stance foci in their study-my adaption phenomenologically 
proffers the existence of four raciolinguistic ideologies as the stance foci of investigation, including discussions of Blackness, Latinidad, Spanish or English usage and competences, or ethno-racial identifications. The videos each take up the topic of Dominican identity and Blackness and are produced by Dominican(-American)s, African Americans, and others who identify as Afro-Latinx. Titles, subject positionalities, dates and metadata of the videos analyzed can be found in Appendix A.

Several notions taken up in the construction of racialized and linguistic value can be located in what Flores and Rosa (2015) term raciolinguistic ideologies. These are ideological frames that conflate racialized bodies to objective linguistic practices. Work in the emerging field of raciolinguistics has begun to explore the remapping of race onto language so that we can understand the ways that language ideologies are implicated in reinforcing already existing hierarchies of power (Lawrence and Aris Forthcoming). For the purposes of this paper, I take up three raciolinguistic ideologies that have been previously defined in the literature (Rosa and Flores 2017; Lippi-Green 2012), as well as a dominant racial ideology that has structured much of the previous understandings of race in fields such as anthropology and linguistics: (i) co-naturalization of language and race; (ii) regimentation of linguistic and racial categories; (iii) standard language ideology; and (iv) genetic race. Each of these ideologies was adapted based on a grounded theory approach, which allowed me to explore how they appeared in the data set. Using the themes drawn out from my discourse analysis as well as the theoretical framework of Rosa and Flores (2017), I demarcate four novel raciolinguistic stance foci that I applied and analyzed in my data: (i) genealogy, DNA ideology; (ii) categorization fallacy; (iii) conaturalization of language and race; and (iv) accent ideology. Definitions of these ideologies are provided in Table 1. The appearance of these ideologies in explicit pronouncements makes central the stances that individuals are taken towards Blackness as a named category.

Table 1. Focal raciolinguistic ideologies.

\begin{tabular}{cl}
\hline Raciolinguistic Ideology & \multicolumn{1}{c}{ Definition } \\
\hline DNA Ideology & $\begin{array}{l}\text { This is any reference to the body, blood, or features in relation to claims of a } \\
\text { particular race or ethnicity. This is also any reference to heritage or genetic } \\
\text { connections to a particular space. Lastly, this included references to genetic } \\
\text { testing and DNA as indicative of ethno-racial identifications. }\end{array}$ \\
\hline Categorization Fallacy & $\begin{array}{l}\text { This is any reference to conflation of race and ethnicity; a confusion about how } \\
\text { to categorize race or ethnicity; or the actual conflation of race and ethnicity. }\end{array}$ \\
\hline Co-Naturalization of Language and Race & $\begin{array}{l}\text { This is when participants conflate their racial identity with a language category. } \\
\text { In some cases, this will also refer to someone not belonging to a race because of } \\
\text { a lack of ability to speak a particular language. }\end{array}$ \\
\hline Accent Ideology & $\begin{array}{l}\text { This is any reference to increased belonging in a particular ethnic group } \\
\text { because of an accent (or lack thereof), or it is references to accents as indicative } \\
\text { of belonging to a particular ethnic group. }\end{array}$ \\
\hline
\end{tabular}

Video data amounted to 128 min of footage, which was hand transcribed and then entered into the qualitative analysis software Dedoose (Dedoose 2018, Version 8.3.35). Collection of the video data consisted of the transcription of each YouTube video in its entirety, as well as a selection of comment threads from each video. Comment selections were taken from the most recent threads that had between 15 and 50 responses in order to ensure that there was enough conversation to analyze engagement with the ideologies presented in the parent comments. Parent comments that did not engage any raciolinguistic ideology were excluded from analysis. For each video, five comment threads displaying raciolinguistic ideologies were selected for coding by hand, with between 15 and 20 child comments coded by two independent raters for the parent comment ideology alongside any additional ideologies that emerged in the discussion. Excerpts were extracted at the 
sentence level in the content videos, while each comment represented an individual excerpt in the conversation analysis.

\subsection{Measures}

To evaluate attitudes toward the stance focus (the focal raciolinguistic ideologies), I weighted three stance dimensions of affect, investment, and alignment for each excerpt on a 1 to 5-point Likert scale, with higher scores indicating greater alignment and investment or more positive affect toward coded ideologies. These measures are operationalized as follows: affect represents "the polarity or quality of the [raciolinguistic ideology]" (Kiesling et al. 2018, p. 688). For this measure, we identify the interlocutor's positive or negative evaluation of the raciolinguistic ideology. Investment is "the dimension of how strongly invested in the talk the speaker is, [and] how committed they signal their relationship to the [raciolinguistic ideology]" (p. 688). This was evidenced through interlocutors' recognition of and perceived willingness to qualify and take part in discussion of the indicated raciolinguistic ideology. Last, alignment refers to interlocutors' agreement, or "alignment", with the respective raciolinguistic ideology. Alignment ranged from explicit agreement to outright objection. Stance dimension definitions can be found in Table 2 .

Table 2. Stance dimension definitions.

\begin{tabular}{cl}
\hline Stance Dimension & \multicolumn{1}{c}{ Definition } \\
\hline Affect & $\begin{array}{l}\text { The positive or negative attitude (or affect) toward the raciolinguistic ideology. Coders take into } \\
\text { account additional emoticon symbols for affective power. A score of } 1 \text { indicates highly negative } \\
\text { feelings toward the ideology, with } 5 \text { indicating highly positive feelings toward the ideology. }\end{array}$ \\
\hline & $\begin{array}{l}\text { The level of interaction with the posited ideology. Coders ask whether the commenters take up the } \\
\text { ideology in their responses. A score of } 1 \text { indicates that the ideology was not taken up at all. In these } \\
\text { cases, the ideology is not marked for affect or alignment. A score of } 5 \text { indicates a complete focus on } \\
\text { the ideology and received a score for affect and alignment. }\end{array}$ \\
Investment & $\begin{array}{l}\text { The level of support for the posited ideology. Coders asked whether the author agrees or disagrees } \\
\text { with the posited ideology. A score of } 1 \text { indicates high disagreement and } 5 \text { indicates complete accord } \\
\text { with the ideology. }\end{array}$ \\
\hline Alignment &
\end{tabular}

The evaluation of these stance dimensions can be illustrated with the YouTube comment in (1), which was left on the "Gina Rodriguez Miss Bala (Spanish)" video. ${ }^{1}$

Her Spanish is good. What y'all talking about? It's a new era for me. I came to this country when I was 12 and I have problems with my Spanish because my goal was to learn perfect English with no accent. So now I speak Spanglish. It's a new culture and I love it.

For this comment, the interlocutor is discussing the public figure's Spanish speaking ability as demonstrated in the content video. The topic is reflective of accent ideology as it refers to good or bad language abilities. Thus, "accent ideology" is coded as the stance focus or raciolinguistic ideology. The affect is coded as positive through the evaluation of this ideology expressed through "good" and "I love it". The investment is high, as the commenter committed to the evaluation of language as a deviation of certainty toward the ideology. The alignment is high because the commenter is demonstrating agreement with standard language ideology through the evaluation of the public figure's language proficiency. Other indicators of affect, alignment, and investment came with the analysis of emojis. Symbols such as 100 were evaluated and incorporated into the weighted scores. Scale rating definitions can be found in Appendix B.

1 This video was analyzed for the purposed of a tangential study and is used here purely for illustrative purposes. https://www.youtube.com/ watch? $\mathrm{v}=\mathrm{ZPSMnSMClfs}$. 


\subsection{Analyses}

Descriptive analyses were completed for the presence of each ideology, represented by the number of tokens over the entire data set. Analyses were also conducted to capture differences in frequency of ideologies based on the subject positionality of the original video posters-Dominican, African American, or Afro-Diasporic. Additional analyses were run to ascertain how ideologies co-occurred and whether co-occurrence differed based on subject positionality. Lastly, each ideology was run separately for the three stance dimensions: affect, investment, and alignment, represented by average weighted scores for each stance dimension. Co-occurring ideologies were analyzed as sets to indicate shifts in stance dimension when both ideologies were present in a statement. Exemplars were extracted from representative excerpts.

\subsection{Methodological Limitations and Future Directions}

Drawing data from online social media platforms allows for a widescale surveying of ideas and language sampling. However, the use of this data is not without its complications. Though the current study focuses on the ways that race-Blackness in particular-is taken up, there is no legitimate way of surveying the ethnic, racial, gender, sexuality, or other social identifications of the participants. In his twitter analysis of linguistic presentation of null subjects in two varieties of Spanish, Adrian Rodriguez Riccelli (2018) notes the drawbacks of using online language data by noting that "[o]ne drawback to this methodology is the difficulty in accessing sociolinguistic and language background, as well as biographical information. Information posted on a user's profile may be inaccurate or absent all together and is currently not easily extracted. Nevertheless, the relative ease of access and exorbitant amounts of data makes for a tempting tool of use. So long as its limitations are acknowledged" (p. 311). In our case, the extraction of large-scale ideological constructions can still be achieved, though we are not able to immediately assess the ways that other characteristics such as gender or sociocultural subjectivity impact the pronouncements. Further, the use of conversation analysis relies on the words being produced, leaving space for an analysis of non-verbal communication in the production of ethno-racial ideologies on these platforms. Nonetheless, the use of the current methodology allows us to move beyond anecdotal or interview data regarding racial ideologies by providing access to large amounts of data with relative ease. In the future, this work could be combined with digital media studies investigating the ways that subject positionality informs social media interaction in order to submit a framework for understanding the subjective nature of race construction on these platforms.

\section{Results}

In this section, I present the appearance of the raciolinguistic ideologies. First, an overall description of the amount of times each raciolinguistic ideology appeared over the entire data sample is presented. Each ideology is then evidenced with a sample of exemplar tokens from the overall data set. Lastly, I provide a brief description of the ways that the ideologies occurred together, showing the inter-relatedness of some of these concepts in strengthening or contesting the boundaries of difference between African Americans and Dominicans. After the presentation of raciolinguistic ideologies, I provide a descriptive analysis of the public engagement through a discussion of the weighted stance dimensions associated with each raciolinguistic ideology in the comments. Additionally, I note the ways that many of these ideologies appear with explicit moments of conflict, solidarity, or anti-Blackness.

Across the entire data set (with videos and comments), there was a total of 933 excerpts, which yielded 925 tokens of the focal raciolinguistic ideologies identified. Table 3 provides an overall summary of the number of times each raciolinguistic ideology appeared. DNA ideology was the most prevalent with 535 appearances. This was closely followed by categorization fallacy with 372 . Overall, the data set suggests that people are still heavily dedicated to negotiating and discussing both scientific race and the modern conceptions of 
nation state and identity. Language, on the other hand, took a backseat in conversations about race, with co-naturalization of language and race only presenting 16 tokens and accent ideology producing 2 . The ideologies are discussed in order of magnitude, with the most frequent occurring first.

Table 3. Raciolinguistic stance foci frequency.

\begin{tabular}{cc}
\hline Ideology & Frequency \\
\hline DNA Ideology & 535 \\
Categorization Fallacy & 372 \\
Co-Naturalization of Language and Race & 16 \\
Accent Ideology & 2 \\
Total & 925 \\
\hline
\end{tabular}

\subsection{DNA Ideology}

While social scientists and the major scholarly organizations to which they belong have generally moved away from race as a biological or scientific concept (Morning 2007), an adherence to eugenic and scientific projects of race persist (Omi and Winant 2014; Morning 2007; Williams 2013). These notions are reified through public narratives of identity based on DNA testing, ultimately linking the life sciences to popular culture (Nelson 2016; Yudell et al. 2016; Roth and Ivemark 2018). DNA ideologies were the most prevalent in the current data set, with genetics as an indicator of racial belonging appearing most often in discussions of ethno-racial belonging. Thus, despite an apparent shift in academic knowledge about race, scientific race is not only persisting, it is dominating ideas about identity and belonging. References to DNA, blood, African, Indian, and European ancestry and heritage were all called on to validate or contest Blackness for Dominicans on the island and in the United States (1). ${ }^{2}$ Moreover, we see reference to DNA as something that is quantifiable, present in the qualifier "more".

(1) Dominicans acknowledge their African ancestry just like they do their Indian and European. I've never heard a Dominican that has obviously African features say that he doesn't have African blood. 2. The Average Dominican has more European DNA than they do African. Yet we don't run around saying we're European. 3. I'd be just as ashamed to claim African ancestors as I am to claim whites/Europeans. Like y'all say "whites were rapist", but you forget that the Africans sold their own to the whites making their rape and mistreatment possible. That's one of the reason we as well as other nations in Latin America developed our own identity.

In this case, we see the calling of the DNA ideology into the construction of a unique Latin American identity that transcends the bounds of Blackness or Whiteness.

Genetic declarations were also found in insistences of phenotypic characteristics as indicative of race (2). Here we see dark skin and African features as demonstrative of both African heritage and supposed belonging in the ethno-racial category Black. In this way, the commenter is privileging notions of "ascribed race", i.e., race assigned to an individual by others and "street race", i.e., the race you think you would be ascribed on the street (López et al. 2018), which cannot be subverted by self-identification since they rely on undeniable physical attributes. This comment is representative of the use of genetic narratives and ideologies to reify notions of phenotype as a marker of racial difference. The commenter goes further to indicate that the sociopolitical aspects that are indexed by Black as a racial category are responsible for the disconnect between true racial categorization-indicated by skin color-and the claiming of racial categorization. Additionally, the commenter

2 Examples are represented exactly as drawn from source, including orthographic irregularities. As internet talk allows for the creation of new forms of talk, respecting the original form of the post provides a more nuanced reading. Additionally, it allows for a more pointed understanding of negotiations of meaning occurring at the level of the word. 
notes the historical subjugation that indicates an alignment with Blackness and Indigeneity, despite the recognition of the negative conditions that such an alignment produces.

(2) la verdad es que hay muchos dominicanos de piel oscura y con rasgos africanos que rechazan su herencia africana. Si la raza negra estuviera en buenas circunstancias, apuesto a que más dominicanos se clasificarían como negros orgullosamente. Sin embargo, como dices, mucha gente latina/dominicana si tiene herencia mezclada y no quiero decir que TODOS los latinos son "africanos". Solo refiero a los dominicanos que se ven muy africanos. Además muchos españoles son racistas contra los latinos así que no podemos olvidar lo que hicieron a nuestros ancestros nativos y africanos a ellos no les importa un carajo de la cultura caribeña.

[The truth is there are a lot of dark skinned Dominicans with African features who deny their African heritage. If the Black race was in better conditions, I bet more Dominicans would identify themselves as proudly Black. In any case, like you say, a lot of Latin@/Dominican people do have mixed heritage and I don't want to say ALL Latin@s are "African". I am only referring to the Dominicans who look very African. Plus, many Spanish people are racist against Latin@s so we can't forget what they did to our native and African ancestors 100 should not be proud of having Spanish blood when they could give a $\mathrm{F}-\mathrm{K}$ about Caribbean culture.].

Commenters who ascribed to the DNA ideology often relied on percentages of ancestry ascertained through DNA profiling services such as 23andMe and AncestryDNA to posit belonging in one group or another, or to contest belonging in any particular group (3). These percentages were often mobilized in conjunction with assertions of phenotype as indicative of racial belonging (3). For hundreds of years, the United States has functioned on a racialized dichotomy of black and white, characterized by what is popularly known as the one-drop rule of hypo-descent, which cast anyone with 1/32 or more African blood into the category of "Black" in the United States (Omi and Winant 1994). In addition to comments about DNA, phenotype and ancestry, genetic distinctions were called into the ratification or contestation of notions of hypo-descent, noting that a small percentage or "one drop" of African blood was not enough to cross into Blackness as a racial identifier (4).

(3) It's mostly Black Americans who want you to be Black lol, if you go to any Dominican DNA video you will see Black Americans commenting. Even though the person is only $30 \%$ Black lol. And most Dominicans are too mixed to be Black. They don't have the skin or hair texture.

(4) am only $10 \%$ African that doesn't make me only African. Some people are delusional and thinks Dominican are only black.

In these examples, we again see the tension between DNA as indicative of racial categorization and imagined phenotypic representations of these boundaries. Nonetheless, with hypo-descent as the organizing principle for racial stratification in the United States, commenters often relied upon these zero sums categorizations of Blackness indicated by African DNA (5). Others contextualized the rule of hypo-descent as an American invention that did not function to categorize people in other parts of the world (6).

(5) when was the last time you did a DNA analysis? If no Sub-Saharan DNA shows up I'll personally call you: a white person, okay.

(6) yes, IN AMERICA. But America isn't the entire world. The reason why Obama is viewed as "black" and not biracial is because of the racist one drop rule that Americans love holding on to.

Quite to the contrary of the one-drop rule in the United States, in the Dominican Republic, one drop of European blood meant that you were cast out of the racial categorization of "Black" and into a racialized concept of "mixed", creating a tripartite conceptualization of race in which Black, white, and mixed can co-exist (Duany 1998). "Mixed" as a racial 
category is quite common in Latin America, stemming from notions of mestizaje developed by Vasconcelos, as the defining characteristic of Latinidad (Hooker 2017).

In contesting the rule of hypo-descent, many relied on notions of mestizaje as an organizing principle for racial stratification (7). Instead of the racial binary created by the rule of hypo-descent, notions of mestizaje are called upon in order to allow for a third category of "mixed", referencing Afro, Euro, and Indigenous descended peoples (8). This incongruency between notions of hypo-descent and mestizaje often prompted conflict (9) and (10). While the Dominican commenter refuses to accept categorization, they attribute the incorrect classification to "Black Americans", which places the blame on a group of people who have acquired systems of racial categorization from the ruling class (9). At the same time, when the African American commenter questions Dominican racial identification practices, it evidences an adherence to concepts of hypo-descent by presupposing that a lack of desire to be categorized as Black must be indicative of a denial of African ancestry (10).

(7) there is a such thing as multiracial dumb ass...and the majority of us ... almost the whole island is multi racial

(8) Ok I am claiming I'm not black but I'm multi racial ... beautiful white lovely native American ... Gorgeous African ... so is this offensive ....

(9) the problem is when black americans claim mixed race latinos as black...we not black we mixed.

(10) why do a lot of them [Dominicans] just refuse to acknowlege that they're black though? ... or at least have african ancestry? That is wild and bizarre

Mestizaje is weaponized against African Americans in a way that does not allow for mixedness to be applicable to African Americans. Mestizaje is thus called into the construction of Latinidad in a way that reinforces the mutual exclusivity between Blackness and Latinidad. Additionally, it at once claims a genetic understanding of race, while rejecting it completely. The contradiction must be maintained in order to reinforce the boundary of difference between Dominicans and African Americans (11).

(11) ... you self haters are nowhere near as mixed as Dominican are ... so stfu..the average Dominican is more European than they are african..I'm not claiming black when I'm 60\% European and 23\% African..the average black American looks like Whoopi Goldberg and obviously black..most of y'all are 80 to $90 \%$ African, look at the dna videos..slavery in the $\mathrm{dr}$ was a breeze compared to America..there was no segregation or Jim Crow laws and the Spaniards freely intermixed with the african and indigenous people. The British on the other hand were ruthless..we have been mixing for more than 500 years..mixed and proud (-)"

Nonetheless, the DNA ideology was also used to promote solidarity between African Americans and Dominicans. Similar physical features were marked as indicative of shared "roots", which indicates alignment with a DNA ideology as a way to engender intra-racial solidarity. Additionally, the comments suggest an adherence to race as a static category that can be achieved with a named and bounded category determination, as shown through the suggestion to "google the different races" (12). In example (13), the commenter says that mixed cannot be a marker of Latinidad since several Latinxs are not mixed. This is a result of atrocities of colonization and slavery that were perpetrated against Afro Cubans as well as African Americans, and indicates a desire to form solidarities based on historical oppression of enslaved ancestors.

(12) Cardi may not be a 100 percent black like most are these days but she does have black roots. Look at Cardi and Hennessy's features, their skin tone and afros as kids. Once again Google the different races and place them in the one they most identify with. Contrary to what most ignorant people think Spanish is not a race bc I'm sure we are not English white men and women.

(13) ... that's not fair to us Afro Latinos who are not mixed. My entire Afro Cuban lineage has NO white ancestry. We are not mixed but are just as Latino as anyone else having 
been in Cuba since slavery. You wanna claim Latino to cover up the multitude of sins committed against Blacks and Indigenous people by hiding behind mixed identity. There are more white Latinos than mixed Latinos. Idk why we lie about this.

The DNA ideology presented a frame for claiming an identity; it was used as a way to place Dominicans both within the boundaries of Blackness that includes African Americans and other Afro-descended people and also as a way to mark them as separate due to a claimed unique mestizaje not shared by African Americans (or Haitians). The way that commenters took up this ideology is explored later in this paper with stance dimensions that nuance the utilization of this ideology.

\subsection{Categorization Fallacy}

Much like Cardi B warned, the presence of a categorization fallacy in the data suggests a general discord in the definition of ethnicity, race, and nationality. As such, much of the debates surrounding who was able to claim Blackness or Latinidad were bound up in the conflation of these categorical notions, such that race and ethnicity were often offered up as simultaneous categorizations. In these cases, "Black" was no longer a racial identification that could be used to promote some sort of solidarity, but rather an ethnic term to create a boundary between African Americans and those who had claim to another national or ethnic "culture". Many of the comments that demonstrated this ideology were offered to "educate" fellow commenters about the distinction between the categories (1) and (2).

(1) Dominicans come in variety of races, not just white dummy. There are also black Dominicans, taino Dominicans and Asian Dominicans. Dominican is only a nationality. Any race can be Dominican as long as they are native born citizens of the island.

(2) I don't think you get the point. Dominican is a nationality. If you say you want a black girl, how do I know if you want Jamaican, Trinidadian, Bahamas, Haitian. If she's darker completed then she's Afro Latina race wise. if your trying make point with black \& Dominican then you have generalized it with different type of black women. Its 2019 c'mon man let's educate each other.

Others justified Dominican denial of Blackness as a result of the term being applied as an ethnic, rather than a racial term (3) and (4). In (3) and (4), we see the explicit connection of Black as an ethnic marker for African Americans rather than a racial marker incorporating a more wide-range of subject positionalities. Moreover, the mention of $100 \%$ in example (4) indicates the frame under which Blackness is constructed in the Dominican republic, with one drop of European ancestry as indicative of a move out of the category of Black.

(3) Tu tiene razon en mucha cosas $k$ dijiste aki hermano ... pero cuando se dice "no soy black soy dominicano" es cuando los dominicans estan hablando de los afroamericanos, a ellos se llaman "black" en USA.

[You are right about a lot of things you say here brother. But when they say, "I am not Black, I'm Dominican" it's when Dominicans are speaking about African Americans. They are called Black in the United States]

(4) Black means African American. I have African in me and that doesn't make me 100 percent black. Silly Americans.

The categorization fallacy was often contested in comment threads, where disambiguating notions of ethnicity, race, and nationality were often accompanied by commentary about levels of intelligence (5). It was in these comments that Latinidad was also imagined as a racial category rather than an ethnic one. Additionally, "Dominican" is posited as an all-encompassing category that supersedes race and ethnicity, while insisting on nationality as the defining characteristic of racial categorizations (6). These comments support narratives of "racial democracy", where Latinidad gives all those who lay claim to it an ability to transcend ethno-racial categorizations as they exist in the context.

(5) They think you telling them they are African Americans, if you call a white Dominican hey white boy they will tell you I'm Dominican, because they think you calling them 
Americans. In Dominican everyone is Dominican black Dominican or light skin or white Dominicans. In Dominican Republic there is colorism but is not like in the US that black and white are divided in DR everyone is Dominican.

(6) Dominican is based on territory and culture of a home land which is a nationality so yeah Dominican is a race.

These comments rely on a comparison with racial structures in the United States, such that racism is a feature unique to the United States. This is similar to Christina Sue (2013) concept of an ideology of non-racism in Mexico, which is maintained through a variety of strategies including the postulation of the U.S. as the only society organized by race. In our case, the prioritization of ethnicity and nationality as the defining category of difference allows Dominicans-or those speaking about race in the Dominican Republic-to negate the existence of a racial hierarchy and of anti-Blackness as an organizing principle of both societies.

Categorization ideologies often relied on citizenship ties in the ratification of ethnoracial belonging (7). Additionally, it allowed for the creation of categories of difference based on historical notions of race in a particular location (8). In this way, the categorization fallacy often called on racialized narratives (or scripts) rather than full historical knowledge in an attempt to create solidarities (9).

(7) Obviously you don't because of what you just said ... 100\% Africans who become a citizen in America are the true African-Americans.

(8) I think Afro indigenous and Latina might be mutually exclusive politically speaking but let's consider the implications of putting these three political locations identities together what we might be referring to is a desire to identify the ways in which people are of African descent indigenous descent and from places and geographies that were established through Spanish.

(9) ... love your comment!!!! Thank you for looking at it from the correct perspective. Many people don't know that slavery and all that it entailed in America lasted way longer than it ever did in the Dominican Republic. The British and their descendants and the Spaniards, French and Portuguese and their descendants did not act in the same manner. In the Dominican Republic, the initial wave of slavery was brutal. However, the new "criollos", which is the name given to the generation of the children of Spaniards who were born in the Dominican Republic and all their descendants just continued to mix with each other without any slavery involved. And this is our real history. So we cannot disqualify one or embrace one when generationally, we haven't been taught that. I understand that in America, the one drop rule has been established and applied as the one and only rule of thumb for anyone of color. This is not a European concept. The descendants of the English created that rule! At the end of the day, there is no such thing as race. We are one race, the human race and the concept of race has only served the purpose of dividing and not uniting us as a human race. So when I see ignorant comments about race or even when they concern my people, I don't entertain those conversations because they're useless! However, I really liked your comment and needed to let you know.

While the DNA ideology provided the basis and justification for racial belonging, the categorization fallacy was more so implicated in the formation of a boundary between Dominicans and other Blacks. This ideology posited Dominican-ness as a racial category in order to blur the stark line between Blackness and Latinidad while also drawing a strong line between themselves and other Blacks both on the island of Hispaniola and in the United States. This ideology was often accompanied by anti-Black sentiments, which will be taken up in subsequent sections.

\subsection{Co-Naturalization of Language and Race}

Language is often posited as the unifying factor in the construction of Latinidad in the United States (Aparicio 1999, 2017b; Flores 1997). As such, the current project hypothesized a large proportion of Dominicanidad and Latinidad to be attributed to the co-naturalization 
of language and race - that is the conflation of race into the bounded notion of a particular language variety such that one who speaks Spanish takes on "Spanish" as their racial category (1). Nonetheless, only five percent of the tokens were represented through the co-naturalization of language and race ideology. These comments not only used language categorizations as racial categorizations but also called on language in order to justify belonging to a particular ethno-racial category (2).

(1) Spanish is a different category from black even though obviously we know now that it's not it is when people use it it's a different category from black ...

(2) I am Dominican I am Hispanic I speak Spanish you know.

There were also contestations of the co-naturalization of language and race (3). These contestations often called into question the use of other bounded language categorization in the identification of individual speakers who have not traditionally been labelled by their language affiliation (4). Assuming the commenter in example (4) speaks both English and Spanish, they note the absurdity of using one language as a racial marker, while the other remains solely an indicator of linguistic ability. Further, if it were used as a racial identifier, it would be reserved for those in England, which would erase the existence of a large group of people who use and speak English as a native language and who are not racialized as English.

(3) Stop talking about education when you said Spanish people. Spanish is a language not an ethnicity, nor a race. Wow the ignorance is appalling.

(4) Contrary to what most ignorant people think Spanish is not a race bc I'm sure we are not English white men and women.

In some cases, the co-naturalization of language in race was used to block entry into a particular racial category. In this case, the inability to speak a particular language invalidated belonging (5). In this example, the speaker was referring to a poster who self-identified as both Cuban American and bilingual in the original video. The comment came after another individual who asked if the original poster could do a version of the video in Spanish in order to educate more people about the existence of Black Latinos. In the context of the United States, where English is the dominant language, the manifestation of this ideology was couched in claims of bilingualism with Spanish representing Latinidad and English representing a belonging within the borders of the United States. Bilingualism as a marker of difference was also posited alongside anti-Black and misogynoir declarations. Bilingualism, thus, becomes a mark of mestizaje, where ideals of the tri-racial were transposed onto multilingualism in the U.S. context (6). More specifically, the comments take up the bounds of Blackness, constructing racial categories by dictating language as the marker for true identity categorization (7).

(5) ... He can't only Dominicans are bilingual.

(6) ... envy jealousy .. why .. cause ys wanna be us .. have our mixture be bilingual.. Dominican men chase Dominican women..black men chase white girls and latinas .whites sre not afraid of us .we mixed with white black native american..no one sees us as black they see African Americans as black ... were never slaves in America. African American never beat white man british.. Dominican beat both white man Spain \& black man haitians.... Dominican was in usa before blacks..black men ur men get on planes to travel to date a poor Dominican girl than educated with bling black woman.....dud i answer u.. Dominican women are desired soooo much.

(7) Dominicans need to stop acting black. Y'all are Dominican. Act Spanish.

Commenters also took part in assigning blame for the creation of these disjunctive categories, indicating Black Americans as the creators of the co-naturalization of language and race, rather than recipients of colonial frames of socialization (8).

(8) It has to be jealousy, In all honesty I can't imagine why else they would take time out of their day to come here and other platforms to tell Dominicans they should identify as "black" and not Dominican. That's why I don't agree with all these new terms 
like "latinx, and Afro Latino". Latinos who do that are just playing in to what black Americans want. And Americans are never satisfied. I remember back in the day when I first moved out here, Americans (specifically black Americans) would notice a person speaking Spanish and instead of taking the time to find out where that person was from they would just label them as Spanish. Now it seems to upset some of them when we say we're Spanish. Which isn't accurate, but that's one of the labels that America has placed on us. Now they're trying to do even more with these new $\mathrm{r}-\mathrm{d}$ terms. I'm Dominican, I may go further to identify as Latino, but that's where it ends.

\subsection{Accent Ideology}

Attributing one's ethno-racial identity to an accent ideology was limited but did manifest in key ways: First, individuals ratified belonging in a particular ethnic category based on accent presentation (1). The ellipsis at the end of this example can be assumed to represent the subtext that her accent provided the evidence of her authentic belonging in the ethnic category, Dominican.

(1) I thought she was a black girl from some random place n not Dominican when I first click the vid until her accent then...

Secondly, some enacted an accent to embody a particular ethnic stance (2). This comment came from a video in which a Nigerian American imitated a Dominican accent while he disavowed belonging in the racial category Black. In this case, the accent ideology appeared in mocking Dominicans who denied Blackness. While accent ideology did not appear in the smaller data set examined here, notions of language and the performance of language as indicative of belonging were suggested.

(2) he try to salsa that shit off and be like "no it's not the same. I no black negro no no nunca nunca no I no black". i'm like no, you're black. "no no no i no black Dominican". I go, I know but you're black.

\subsection{Co-Occurrence of Raciolinguistic Ideologies}

Examinations of the raciolinguistic ideologies that were presented together give us an indication of how these ideologies are marshaled in the creation of ethno-racial boundaries between Dominicans and African Americans. Of all of the co-occurrences the most common co-occurrence of ideologies was categorization with (or alongside) the DNA ideology, with 106 instances of overlapping between the ideologies. The second-most commonly cooccurring ideology was the categorization fallacy alongside co-naturalization (16), followed by the DNA ideology with the co-naturalization ideology (12). Overall, the co-occurrences reinforced the strength between genetic conceptualizations of race and the terminology that is used to categorize individuals in different contexts. From this analysis, it seems that while language often functions to create and uphold notions of Latinidad (often being mobilized as evidence that Dominicans are not Black but rather Spanish), DNA functions to confirm (or to disprove) Blackness. The lack of co-occurrence between DNA and co-naturalization of language and race suggests the stronghold of a mutual exclusivity between Blackness and Latinidad in these data. Nonetheless, there was a strong co-occurrence between ideologies that aided in the definition of the African American/Dominican boundary of difference with the DNA ideology being used to support the categorization fallacy that conflated ethnicity, race, and nationality marking Dominican as a racial category. Table 4 provides an overview of the number of tokens that were coded for two ideologies at the same time. 
Table 4. Co-occurrence of focal raciolinguistic ideologies.

\begin{tabular}{lcccc}
\hline & $\mathbf{( 1 )}$ & $\mathbf{( 2 )}$ & $\mathbf{( 3 )}$ & $\mathbf{( 4 )}$ \\
\hline (1) Accent & - & & & \\
(2) Categorization & 1 & - & - & \\
(3) Co-naturalization & 0 & 16 & 12 & - \\
(4) DNA & 1 & 106 & \\
\hline
\end{tabular}

\subsection{Stance Dimension Weights by Ideology}

While the frequency of ideologies gives us an indication of how racial categories are being constructed, the mention of the ideology does not tell us whether the public is taking the ideology up or contesting it in their comments. The following analysis allows for a more refined understanding of the ways that these ideologies were represented in conversations about Dominicans and Blackness. The stance dimensions (affect, investment, alignment) for each excerpt were weighted on a 1-5-point Likert scale, with higher scores indicating greater alignment and investment or more positive affect toward coded ideologies. Across all of the data, the mean scores for each (affect, alignment, and investment) are presented for each raciolinguistic ideology as seen in Table 5. As we can see, the scores reflected a narrow window of variation between each raciolinguistic ideology. ${ }^{3}$

Table 5. Mean stance dimension weights by ideology.

\begin{tabular}{ccccc}
\hline & Accent & Categorization & Co-Naturalization & DNA \\
\hline Affect & 3 & 2.76 & 2.762 & 3.224 \\
Alignment & 4 & 3.01 & 3.482 & 3.988 \\
Investment & 3.5 & 3.108 & 3.798 & 3.302 \\
\hline
\end{tabular}

Nevertheless, the variations provide interesting information about the ways that the ideologies are being mobilized to create boundaries of difference. Taking each raciolinguistic ideology separately, the highlighted scores demonstrate some key differences as shown in Table 6. Scores were measured for the stance dimension by subject positionality for each raciolinguistic ideology investigated. Averages were taken across each ethno-racial identifier, with one video from an African American, two from Panamanian, one from Cuban, one from Nigerian, and five from Dominican subject positionalities. Overall, the categories analyzed for the stance dimensions confirm the strength of the DNA ideology in the construction of race, with alignment being the highest for all subject positionalities. The DNA ideology displayed an average score of 3.988 on alignment, followed by co-naturalization of language and race (3.483) and then categorization fallacy (3.01). It is important to note that the scores presented for each ideology do not indicate a neutrality but rather a trend toward an equal number of individuals who were not aligned (0-1) alongside those who were completely aligned (5). In fact, there were rarely times where an explicit score of 3 was given as most commenters had strong feelings and opinions associated with their comments.

3 Note, accent ideology was eliminated from this analysis as it only appeared in two instances. 
Table 6. Raciolinguistic ideology by subject positionality.

\begin{tabular}{|c|c|c|c|c|c|}
\hline \multicolumn{6}{|c|}{ Co-Naturalization Ideology by Subject Positionality } \\
\hline & African American & Cuban & Dominican & Nigerian American & Panamanian \\
\hline Affect & 3 & 2.75 & 2.31 & 3 & 2.75 \\
\hline Alignment & 4.14 & 3.5 & 2.77 & 3.5 & 3.5 \\
\hline Investment & 3.62 & 4.5 & 2.12 & 4 & 4.75 \\
\hline \multicolumn{6}{|c|}{ DNA Ideology by Subject Positionality } \\
\hline & African American & Cuban & Dominican & Nigerian American & Panamanian \\
\hline Affect & 3.26 & 3.04 & 3.2 & 3.33 & 3.29 \\
\hline Alignment & 3.93 & 4.02 & 4.01 & 3.91 & 4.07 \\
\hline Investment & 3.37 & 2.95 & 3.1 & 3.35 & 3.74 \\
\hline \multicolumn{6}{|c|}{ Categorization Fallacy by Subject Positionality } \\
\hline & African American & Cuban & Dominican & Nigerian American & Panamanian \\
\hline Affect & 2.84 & 2.89 & 2.7 & 2.71 & 2.66 \\
\hline Alignment & 2.9 & 3.33 & 2.85 & 3 & 2.97 \\
\hline Investment & 2.34 & 2.87 & 3.21 & 3.94 & 3.18 \\
\hline
\end{tabular}

Though the co-naturalization of language and race was not as prevalent in the data as hypothesized, investment scores show the ideology to be taken up more by non-Dominicans than by Dominicans themselves. In fact, the Dominican videos not only elicited minimal participation in the ideology, but also when the ideology was introduced, it was mostly contested eliciting a slight trend toward disagreement with the ideology (2.77). In other words, when people brought up the co-naturalization of language and race, it was mostly to oppose its validity. The scores indicate a lack of participation in the deployment of co-naturalization of language and race as a valid tool for the construction of racial identity. Lastly, the video produced by the Nigerian American elicited the most investment in the categorization fallacy (3.94).

\subsection{Anti-Haitian and Anti-African American Sentiments Taken up in Conflict and Solidarity}

Another fruitful example of the way boundaries of difference were created was explored through an examination of moments of conflict and solidarity. Three codes were developed in order to explore these moments: (i) Anti-Blackness; (ii) inter-ethnic conflict; and (iii) inter-ethnic solidarity. Anti-Blackness referred to moments where there was a combined use of the $\mathrm{n}$ word with derogatory comments against "Black" identity categorizations (1). Inter-ethnic conflicts, on the other hand, were characterized by an explicit mention of disagreement between individuals regarding identification practices (2). Inter-ethnic solidarities were characterized by explicit moments of racial accord between individuals from different Black subjectivities (3).

(1) I never seen a Dominican as black or blacker than Godfrey, this $n-a$ burnt $y^{\prime}$ all got us confused with Haitians ... the darkest we go is will smith color

(2) ... parts of our culture may come from West Africa (nothing to do with American blacks) ... but American blacks themselves, yes they envy us Dominicans becuz of our mixed race heritage.

(3) She never said that she wasn't black and being that this ignorant ass comment got pinned disgusted me. You do know that the freeways from West Africa came over to the Caribbean and Latin America first right? Before the slave trade. How can black people be so ignorant to black history. Latina is a culture not a damn race.

What is interesting is the ways that these moments of anti-Blackness, conflict, and solidarity appeared in conjunction with the raciolinguistic ideologies explored. In Table 7, we see the number of times a raciolinguistic ideology appeared alongside an instance of anti-Blackness, conflict, or solidarity over the entire data set. 
Table 7. Conflict and solidarity by raciolinguistic ideology.

\begin{tabular}{ccccc}
\hline & DNA & Co-Naturalization & Category & Accent \\
\hline Anti-Blackness & 40 & 2 & 32 & 0 \\
Inter-ethnic Conflict & 26 & 1 & 12 & 0 \\
Inter-ethnic Solidarity & 69 & 3 & 49 & 0 \\
\hline
\end{tabular}

Based on frequency, the data indicate a high presence of moments of solidarity (69) alongside genetic explanations of race, which evidences a pan-racial solidarity. Nonetheless, moments of anti-Blackness alongside the DNA ideology show that genetic race is also used to create boundaries of separation and to contest belonging in a pre-determine racial group (40). Genetic race prevailed in Anti-Haitian sentiments, with comments noting phenotypical differences between Haitians and Dominicans (4). It is assumed here that Morgan Freeman, who has a deep brown skin complexion, is more representative of Blackness than Arod, who has a caramel-colored skin complexion. In this case, a caramel skin complexion shows mixed-ness, which pushes him out of the categorization of Black. This strategy was also used to distance Dominicans from African Americans (5), with African American culture often being aligned with notions of paucity and depravity, even in moments of attempted solidarity (6).

(4) Haitian look like Morgan freemen ..so do afro Americans. Dominican look like Arod

(5) If Dominicans are so "racist" and "confused" why do you African-American men go down there for an orgasm? I never see you self haters visiting Haiti or Africa? Or predominantly black countries..y'all stay going to Dominican republic to fuck mixed light skin women with good hair..you guys hate your own black women you hate black features so much so that you have to go down to a predominately mixed country to chase after light skin women! You black men need to worry about your community and being a father! Y'all stay praising light skinned mixed women but don't like ur own women..sad existence...worry about your own damn self instead of worrying about people of a different culture and background than you.

(6) I don't think that they hate Africans or African Americans. I think it is the negative image given to them by the media many times, especially about African Americans. What I think many dislike are the street life/culture of African Americans which gets more promoted everywhere and make people think thats how all African Americans are or act even though I know thats not the case. Stupid media just pick the bad apples to represent African Americans just like I see many African Americans picking the bad apples to represent all of us Dominicans and say that were like that which is bs.

African Americans contested the anti-Blackness, suggesting that Dominicans (as well as others) benefited from Black culture while also creating a hierarchy of superiority over African Americans (7). They also contested the idea of mestizaje, re-inserting notions of hypo-descent as the prevailing racial ideology (8).

(7) Kings $\mathrm{n}$ queens of colorism, nationalistic pride and coat tale riding off black culture but hate blackness. $\mathrm{N}$ feel superior for 0 reason.

(8) African American question: why do a lot of them just refuse to acknowlege that they're black though?..or at least have african ancestry? That is wild and bizarre.

It is worth noting that the videos represented an even split of Black diasporic solidarity and Inter-ethnic conflict and boundary justifications. Of the five videos presented by those who claimed Dominican identities, just two represented inter-ethnic conflict. Nonetheless, the comment sections of each video contained the majority of the discord, with $90.3 \%$ of the anti-Blackness and $91.5 \%$ of the inter-ethnic conflict being located in the comments. While social media influencers and content producers intended to create solidarities, narratives of DNA and categorization fallacies prevailed, ultimately resulting in a strengthened boundary of difference between African Americans and Dominicans. 


\section{Discussion}

The subject of inter-racial conflict forms the cornerstone of many race studies, but inter-ethnic conflict is far less studied in the United States (examples of ethnic conflict studies can be found in European contexts). In fact, the boundaries of difference drawn between groups that can exist within one census box is rarely examined, though many have noted the effects of homogenization in studies of Latinidad (Oro 2016; Aparicio 2017a, 2019). Additionally, the way that the terms race, ethnicity, and nationality have been operationalized in these contexts offers a foundation for the development of U.S. racial logics (e.g., Blackness, whiteness, and racism) (De Genova and Ramos-Zayas 2003; Hoy 2010). The current study presented several examples of raciolinguistic ideologies from individual YouTube users. While many of these examples seem to come from one user, each excerpt represented a unique assertion by different individuals. Although the methodology did not allow for a survey of the subject positionality of each of these users, the fact that - even down to the phrasing - the ideologies represented were repeated by different users is indicative of the scripted nature of raciolinguistic ideologies in this context. Nevertheless, focusing on the ways that the raciolinguistic ideologies surfaced within interethnic conflict allows for a nuanced understanding of racial construction. While the construction of Blackness continues to rely on colonial logics of scientific race, taken up in the DNA ideology, the mobilization of national borders and language allowed for a novel racialization of Latinidad that marked it as distinct from Blackness. Nonetheless, the use of language as a distinguishing feature of Latinidad seems to be part of the larger project of Latinidad, not necessarily taken up by Dominicans themselves, who often recognize that you can both fit into the scientific racial logics of Blackness while possessing the cultural norms that are being marked as mutually exclusive. Since language is enregistered as the boundary making element between Blackness and Latinidad, Dominicans are often forced into a position of either accepting or contesting the boundary in a move towards their own self-determination.

Nevertheless, DNA narratives were often posited as objective fact adding to the literature showing the subjective nature of "scientific race" (Morning 2007; Williams 2013). Users evoked DNA as a way to both construct and deconstruct boundaries of belonging. Further, the use of this ideology in conjunction with the categorization ideology was often mobilized in order to promote a conflation of race and ethnicity that supported a mutual exclusivity between Black and Latino as pan-racial categories. This mutual exclusivity was further constructed by the co-naturalization of language and race ideology, which posited language ability as the true indication of race. Data from the current study provide evidence of the ways that language is being used to transcend the boundaries of "ascribed" and "street race", such that individuals are able to take a stance toward or away from assigned racial categories and even physical representations of race through the use or knowledge of particular language not generally indexed to their ascribed or street race. Although many Latinxs may transcend the boundaries of Blackness and Latinidad, Blackness has been a defining characteristic of U.S. social order, linking individuals to notions of poverty, violence, ignorance, and laziness (Fanon 1995; Yancy 2012). Therefore, it is no surprise that for Dominican(-Americans) a negotiation and possible distancing from Blackness may be employed in the performance of racial identity.

In looking at the presented data from an anti-racist stance, I turn to the question of social justice and liberation. I ask, "what happens when you fight for the visibilization of African descended people without disrupting the colonial logics under which you were socialized"? It seems that without centering decoloniality in constructions of self and others, one ultimately reproduces colonial logics. Ethno-racial logics may manifest differently based on the terminology and language given to the structures. However, the result is the same-erasure and dehumanization via the indexing of Blackness with stereotypes of urban crime (ghetto) and undesirability. In this paper, anti-Black stereotypes were most often attributed to African Americans. As the most established Afro-descended population within the colonial frame of the United States, it makes sense that these ideologies would 
have taken hold, even for newly arrived populations. The fact that these ideologies occur even within a population that may suffer from negative stereotypes related to antiBlackness proves the strength of colonial formations of power. So terminology matters-the way that we marshal identity categories for ourselves and others has an effect on our ability to create inter-ethnic solidarity. When does one get to claim a Black identity? Do they have to look Black? Do they have to have a certain percentage of African DNA? Do they have to speak a certain language? Or have a certain accent? The debate about Blackness in these forums often called on colonial logics of scientific race and reproduced structures of white supremacy. Those who have limited ability to negotiate Blackness through language or culture because of physical characteristics such as skin color and hair texture were often the ones who engaged in acts of policing Blackness, calling on notions of hypo-descent while also questioning authenticity based on linguistic and cultural practices that were seen as mitigating whiteness. The policing of Blackness is a direct re-formulation of colonial structures of power. In trying to fight for pieces of this power, Afro-descended people often rely on the same tools that uphold white supremacy. In doing this, they are often forfeiting liberatory action for debates on description and a place in the already defined system.

Funding: This research received no external funding.

Conflicts of Interest: The authors declare no conflict of interest. 
Appendix A. Video Data

\begin{tabular}{|c|c|c|c|c|c|}
\hline Video Title & $\begin{array}{c}\text { Subject } \\
\text { Positionality }\end{array}$ & Date Posted & URL & $\begin{array}{c}\text { \# of } \\
\text { Overall } \\
\text { Comments }\end{array}$ & $\begin{array}{c}\text { \# of Views } \\
\text { (as of 10/1/2020) }\end{array}$ \\
\hline $\begin{array}{l}\text { Dominicans are not } \\
\text { black explained } \bullet \text { (read } \\
\text { description below) }\end{array}$ & Dominican & 24 November 2019 & $\begin{array}{c}\text { https: } \\
\text { //www.youtube. } \\
\text { com/watch?v= } \\
\text { oseIP_fmFds }\end{array}$ & 604 & 4697 \\
\hline $\begin{array}{l}\text { Do Are Dominicans } \\
\text { black??? Final answer! } \\
\text { (with pictures of my } \\
\text { family }\end{array}$ & Dominican & 27 August 2018 & $\begin{array}{c}\text { https: } \\
\text { //www.youtube. } \\
\text { com/watch?v= } \\
\text { 0TcfxRX3Nco }\end{array}$ & 2216 & 46,240 \\
\hline $\begin{array}{l}\text { Why Dominicans say } \\
\text { they are not Black they } \\
\text { Dominican }\end{array}$ & Cuban & 28 February 2019 & $\begin{array}{c}\text { https: } \\
\text { //www.youtube. } \\
\text { com/watch?v= } \\
\text { AZlbPxL_zJE }\end{array}$ & 808 & 12,595 \\
\hline $\begin{array}{l}\text { Dominicans_“The } \\
\text { Self-Hating Black } \\
\text { Latinos ... " ㅇ-:) }\end{array}$ & Dominican & 2 February 2019 & $\begin{array}{c}\text { https: } \\
\text { //www.youtube. } \\
\text { com/watch?v= } \\
\text { aSMcM4ax0bA }\end{array}$ & 816 & 12,978 \\
\hline $\begin{array}{l}\text { I'm not Black, I'm } \\
\text { Dominican }\end{array}$ & $\begin{array}{c}\text { Dominican and } \\
\text { Panamanian }\end{array}$ & 29 December 2019 & $\begin{array}{c}\text { https: } \\
\text { //www.youtube. } \\
\text { com/watch?v= } \\
\text { JKBezkCiTJ8 }\end{array}$ & 616 & 8525 \\
\hline $\begin{array}{c}\text { Dominican Girl Says } \\
\text { SHES NOT BLACK goes } \\
\text { viral WHAT ARE YOUR } \\
\text { THOUGHTS? }\end{array}$ & Dominican & 22 January 2019 & $\begin{array}{c}\text { https: } \\
\text { / / www.youtube. } \\
\text { com/watch?v= } \\
\text { wZDQjPX0-1E\& } \\
\text { feature=youtu.be }\end{array}$ & 1002 & 24,642 \\
\hline $\begin{array}{c}\text { Cardi Says She's Afro } \\
\text { Latina }\end{array}$ & Black (U.S.) & 29 June 2019 & $\begin{array}{c}\text { https: } \\
\text { / / www.youtube. } \\
\text { com/watch?v=w- } \\
\text { SBX2qPPa0 }\end{array}$ & 11,689 & 493,388 \\
\hline $\begin{array}{c}\text { Cardi B is an Afro Latino } \\
\text { Now I An Afro Latina } \\
\text { Opinion }\end{array}$ & Panamanian & 26 June 2019 & $\begin{array}{c}\text { https: } \\
\text { / / www.youtube. } \\
\text { com/watch?v=Lr1 } \\
\text { nJzcqy4g }\end{array}$ & 856 & 28,810 \\
\hline $\begin{array}{l}\text { Godfrey Impersonates } \\
\text { Dominicans Refusing to } \\
\text { Accept They're Black } \\
\text { (Flashback) }\end{array}$ & Nigerian American & 4 June 2020 & $\begin{array}{c}\text { https: } \\
\text { //www.youtube. } \\
\text { com/watch?v= } \\
\text { Xxpgx0Dts6w }\end{array}$ & 3369 & 244,569 \\
\hline $\begin{array}{c}\text { BLACKS VS } \\
\text { DOMINICANS }\end{array}$ & $\begin{array}{l}\text { Dominican } \\
\text { (woman) }\end{array}$ & 4 June 2020 & $\begin{array}{c}\text { https: } \\
\text { //www.youtube. } \\
\text { com/watch?v= } \\
\text { VFBE9ifRBDM }\end{array}$ & 948 & 4786 \\
\hline
\end{tabular}




\section{Appendix B. Stance Dimensions}

\begin{tabular}{|c|c|c|c|c|c|}
\hline $\begin{array}{c}\text { Stance } \\
\text { Dimension }\end{array}$ & 1 & 2 & 3 & 4 & 5 \\
\hline AFFECT & $\begin{array}{l}\text { This indicates } \\
\text { strong negative } \\
\text { feelings towards } \\
\text { the stance focus }\end{array}$ & $\begin{array}{l}\text { This indicates } \\
\text { negative feelings } \\
\text { towards the stance } \\
\text { focus }\end{array}$ & $\begin{array}{l}\text { This indicates } \\
\text { neither negative nor } \\
\text { positive feelings } \\
\text { towards the stance } \\
\text { focus }\end{array}$ & $\begin{array}{l}\text { This indicates } \\
\text { positive feelings } \\
\text { towards the stance } \\
\text { focus }\end{array}$ & $\begin{array}{l}\text { This indicates strong } \\
\text { positive feelings } \\
\text { toward the stance } \\
\text { focus }\end{array}$ \\
\hline INVESTMENT & $\begin{array}{l}\text { This indicates very } \\
\text { minimum } \\
\text { investment in the } \\
\text { claim towards the } \\
\text { stance focus }\end{array}$ & $\begin{array}{l}\text { This indicates low } \\
\text { investment in the } \\
\text { claim towards the } \\
\text { stance focus }\end{array}$ & $\begin{array}{l}\text { This indicates } \\
\text { neither high nor low } \\
\text { investment in the } \\
\text { claim towards the } \\
\text { stance focus }\end{array}$ & $\begin{array}{l}\text { This indicates } \\
\text { medium investment } \\
\text { in the claim towards } \\
\text { the stance focus }\end{array}$ & $\begin{array}{l}\text { This indicates high } \\
\text { investment in the } \\
\text { claim towards the } \\
\text { stance focus }\end{array}$ \\
\hline ALIGNMENT & $\begin{array}{l}\text { This indicates high } \\
\text { disalignmentin the } \\
\text { orientation } \\
\text { towards the stance } \\
\text { focus as either the } \\
\text { original poster, or } \\
\text { the commenters } \\
\text { prior }\end{array}$ & $\begin{array}{l}\text { This indicates } \\
\text { some disalignment } \\
\text { in the orientation } \\
\text { towards the stance } \\
\text { focus as either the } \\
\text { original poster, or } \\
\text { the commenters } \\
\text { prior }\end{array}$ & $\begin{array}{l}\text { This indicates } \\
\text { neither alignment or } \\
\text { disalignment in } \\
\text { orientation towards } \\
\text { the stance focus as } \\
\text { either the original } \\
\text { poster, or the } \\
\text { commenters prior. }\end{array}$ & $\begin{array}{l}\text { This indicates some } \\
\text { agreement (or } \\
\text { alignment) in } \\
\text { orientation towards } \\
\text { the stance focus as } \\
\text { either the original } \\
\text { poster, or the } \\
\text { commenters prior }\end{array}$ & $\begin{array}{l}\text { This indicates high } \\
\text { agreement (or } \\
\text { alignment) in } \\
\text { orientation towards } \\
\text { the stance focus as } \\
\text { either the original } \\
\text { poster, or the } \\
\text { commenters prior }\end{array}$ \\
\hline
\end{tabular}

\section{References}

Alim, H. Sami, John R. Rickford, and Arnetha F. Ball. 2016. Introducing raciolinguistics: Racing language and languaging race in hyperracial times. In Raciolinguistics: How Language Shapes our Ideas About Race. New York: Oxford University Press, pp. 1-30.

Agha, Asif. 2005. Voice, footing, enregisterment. Journal of Linguistic Anthropology 15: 38-59. [CrossRef]

Aparicio, Francis. 1999. Reading the "Latino" in Latino studies: Toward re-imagining our academic location. Discourse 21: 3-18.

Aparicio, Frances R. 2017a. (Re) constructing Latinidad: The Challenge of Latina/o Studies. A Companion to Latina/o Studies 18: 39-48.

Aparicio, Frances R. 2017b. Latinidad. In Keywords in Latina/o Studies. New York: NYU Press, pp. 113-18.

Aparicio, Frances R. 2019. Negotiating Latinidad: Intralatina/o Lives in Chicago. Champaign: University of Illinois Press, Volume 1.

Bailey, Benjamin. 2000. Language and negotiation of ethnic/racial identity among Dominican Americans. Language in Society 1: 555-82. [CrossRef]

Bailey, Benjamin H. 2002. Language, Race, and Negotiation of Identity: A Study of Dominican Americans. New York: LFB Scholarly Pub.

Bailey, Benjamin. 2007. Language alternation as a resource for identity negotiations among Dominican American bilinguals. In Style and Social Identities: Alternative Approaches to Linguistic Heterogeneity. Berlin: De Gruyter, pp. 29-56.

Bloom, Nicholas. Forthcoming. The Reactionary Romance of American Slave Revolt: Telling the Story of the 1811 German Coast Uprising. Slavery \& Abolition: A Journal of Slave and Post-Slave Studies. under review.

Boas, Franz. 1982. Race, Language, and Culture. Chicago: University of Chicago Press.

Bucholtz, Mary, and Kira Hall. 2005. Identity and interaction: A sociocultural linguistic approach. Discourse Studies 7: 585-614. [CrossRef]

Cahuas, Madelaine. 2019. Interrogating absences in Latinx theory and placing blackness in Latinx geographical thought: A critical reflection. Society E Space 38: 6.

Candelario, Ginetta. 2007. Color matters: Latina/o racial identities and life chances. A Companion to Latina/o Studies 1: 337.

Coupland, Nikolas. 2007. Style: Language Variation and Identity. Cambridge: Cambridge University Press.

Crenshaw, Kimberle. 1991. Mapping the margins: Intersectionality, identity politics, and violence against women of color. Stanford Law Review 43: 1241-99. [CrossRef]

Davis, F. James. 2010. Who Is Black?: One Nation's Definition. University Park: Penn State Press.

De Genova, Nicholas, and Ana Y. Ramos-Zayas. 2003. Latino racial formations in the United States: An introduction. Journal of Latin American Anthropology 8: 2-16. [CrossRef]

Dedoose 2018. Web Application for Managing, Analyzing, and Presenting Qualitative and Mixed Method Research Data. Version 8.3.35. Los Angeles: SocioCultural Research Consultants, LLC, Available online: www.dedoose.com (accessed on 3 October 2020).

Delgado, Richard, and Jean Stefancic. 2017. Critical Race Theory: An Introduction. New York: NYU Press, Volume 20.

Duany, Jorge. 1998. Reconstructing racial identity: Ethnicity, color, and class among Dominicans in the United States and Puerto Rico. Latin American Perspectives 25: 147-72. [CrossRef]

Duany, Jorge. 2008. Quisqueya on the Hudson: The transnational identity of Dominicans in Washington Heights, Dominican Research Monographs. New York: The CUNY Dominican Studies Institute.

Fairclough, Norman. 2001. Language and Power. London: Pearson Education. 
Fanon, Frantz. 1967. Black Skin, White Masks. London: Pluto Press.

Fanon, Frantz. 1995. Black skin, white mask. San Francisco.: California Newsreel.

Flores, Juan. 1997. Pan-latino/trans-latino: Los puertorriqueños en el "nuevo New York". Revista de Ciencias Sociales 2: 90-121.

Flores, Juan, and Román. 2009. Triple-consciousness? Approaches to Afro-Latino culture in the United States. Latin American and Caribbean Ethnic Studies 4: 319-28. [CrossRef]

Flores, Nelson, and Jonathan Rosa. 2015. Undoing appropriateness: Raciolinguistic ideologies and language diversity in education. Harvard Educational Review 85: 149-71. [CrossRef]

Hall, Sturart. 1996. Race, Articulation, and Societies Structured in Dominance. In Black British Cultural Studies: A Reader. Edited by Houston A. Baker Jr., Manthia Diawara and Ruth H. Lindeborg. Chicago: University of Chicago Press, pp. 16-60. First published 1980.

Hartman, Saidiya V. 1997. Scenes of Subjection: Terror, Slavery, and Self-Making in Nineteenth-Century America. New York: Oxford University Press on Demand.

Hooker, Juliet. 2016. Black Lives Matter and the paradoxes of US Black politics: From democratic sacrifice to democratic repair. Political Theory 44: 448-69. [CrossRef]

Hooker, Juliet. 2017. Theorizing Race in the Americas: Douglass, Sarmiento, Du Bois, and Vasconcelos. Oxford: New York.

Hoy, Vielka Cecilia. 2010. Negotiating among invisibilities: Tales of Afro-latinidades in the United States. In The Afro-Latin@ Reader: History and Culture in the United States. Durham: Duke University Press, pp. 426-30.

Johnstone, Barbara. 2007. Linking identity and dialect through stancetaking. In Stance Taking in Discourse: Subjectivity, Evaluation, Interaction. Amsterdam: John Benjarnins, pp. 49-68.

Johnstone, Barbara. 2009. Stance, style, and the linguistic individual. Stance: Sociolinguistic Perspectives 29: 52.

Kendi, Ibram X. 2019. How to Be an Antiracist. New York: Random House.

Kiesling, Scott F., Umashanthi Pavalanathan, Jim Fitzpatrick, Xiaochuang Han, and Jacob Eisenstein. 2018. Interactional stancetaking in online forums. Computational Linguistics 44: 683-718. [CrossRef]

Lawrence, Anna, and Clemons Aris. Forthcoming. (Mis)languaging and (Mis)translating Identity: Racialization of Latinidad in the U.S. mediascape. Latino Studies. under review.

Lippi-Green, Rosina. 2012. English with an Accent: Language, Ideology and Discrimination in the United States. London: Routledge.

Lopez, Ian F. Haney. 1994. The social construction of race: Some observations on illusion, fabrication, and choice. Harvard Civil Rights-Civil Liberties Law Review 29: 1-62.

López, Nancy, Edward Vargas, Melina Juarez, Lisa Cacari-Stone, and Sonia Bettez. 2018. What's your "street race"? leveraging multidimensional measures of race and intersectionality for examining physical and mental health status among latinxs. Sociology of Race and Ethnicity 4: 49-66. [CrossRef]

Montagu, Ashley. 1997. Man's Most Dangerous Myth: The Fallacy of Race. Ranham: Rowman \& Littlefield.

Morning, Ashley. 2007. "Everyone Knows It's a Social Construct": Contemporary Science and the Nature of Race. Sociological Focus 40: 436-54. [CrossRef]

Nagel, Joane. 1994. Constructing ethnicity: Creating and recreating ethnic identity and culture. Social Problems 41: 152-76. [CrossRef]

Nagel, Joane. 2003. Race, Ethnicity, and Sexuality: Intimate Intersections, Forbidden Frontiers. New York: Oxford University Press, p. ii308.

Nelson, Alondra. 2016. The Social Life of DNA: Race, Reparations, and Reconciliation after the Genome. Boston: Beacon Press.

Nilep, Chad. 2006. "Code switching" in sociocultural linguistics. Colorado Research in Linguistics 19. [CrossRef]

Ochs, Elinor. 1993. Constructing social identity: A language socialization perspective. Research on Language and Social Interaction 26: 287-306. [CrossRef]

Ochs, Elinor, Alessandro Duranti, and Charles Goodwin. 1992. Rethinking Context: Language as an Interactive Phenomenon. Edited by Alessandro Duranti and Charles Goodwin. Cambridge: Cambridge University Press, pp. 335-58.

Omi, Michael, and Howard Winant. 1994. Racial formation in the United States: From the 1960s to the 1990s, 2nd ed. New York: Routledge.

Omi, Michael, and Howard Winant. 2014. Racial Formation in the United States. London: Routledge.

Oro. 2016. "Ni de aquí, ni de allá": Garífuna Subjectivities and the Politics of Diasporic Belonging. In Afro-Latin@ s in Movement. New York: Palgrave Macmillan, pp. 61-83.

Riccelli. 2018. Espero estén todos: The distribution of the null subordinating complementizer in two varieties of Spanish. In Language Variation and Contact-Induced Change. Amsterdam: John Benjamins, pp. 299-333.

Rosa, Jonathan, and Nelson Flores. 2017. Unsettling race and language: Toward a raciolinguistic perspective. Language in Society 46: 621-47. [CrossRef]

Roth, Wendy D., and Biorn Ivemark. 2018. Genetic options: The impact of genetic ancestry testing on consumers' racial and ethnic identities. American Journal of Sociology 124: 150-84. [CrossRef]

Rubinstein-Ávila, Eliane. 2007. From the Dominican Republic to Drew High: What counts as literacy for Yanira Lara? Reading Research Quarterly 42: 568-89. [CrossRef]

Shange, Savannah. 2019. Black girl ordinary: Flesh, carcerality, and the refusal of ethnography. Transforming Anthropology 27: 3-21. [CrossRef]

Sue, Christina A. 2013. Land of the Cosmic Race: Race Mixture, Racism, and Blackness in Mexico. New York: Oxford University Press.

Telles, Edward. 2014. Pigmentocracies: Ethnicity, Race, and Color in Latin America. UNC Press Books. Chapel Hill: The University of North Carolina Press. 
Torres-Saillant, Silvio. 1999. Introduction to Dominican Blackness, CUNY Dominican Studies Institute. New York: City College of New York. Urciuoli, Bonnie. 1995. Language and borders. Annual Review of Anthropology 24: 525-46. [CrossRef]

Wilderson, Frank B., II. 2010. Red, White E Black: Cinema and the Structure of US Antagonisms. Durham: Duke University Press.

Williams, Johnny E. 2013. Biological Pre-emption: “Race”, Class, and Genomics. Sociology Compass 7: 711-25. [CrossRef]

Yancy, George. 2012. Look, a White!: Philosophical Essays on Whiteness. Philadelphia: Temple University Press.

Yudell, Michael, Dorothy Roberts, Rob DeSalle, and Sarah Tishkoff. 2016. Taking race out of human genetics. Science 351: 564-65. [CrossRef] [PubMed]

Yuval-Davis, Nira. 2011. Power, Intersectionality and the Politics of Belonging. Aalborg: FREIA (Feminist Research Center in Aalborg), Aalborg University. 